\title{
The chemical composition and ruminal degradability of maize silages depending on the cultivar and mowing height at harvest
}

\author{
H. Kruczyńska ${ }^{1}$, K. Darul', W. Nowak ${ }^{1}$ and I. Kowalik ${ }^{2}$ \\ 'Department of Animal Nutrition and Feed Management, \\ 'Institute of Agricultural Engineering, \\ August Cieszkowski Agricultural University \\ Wolyniska 33, 60-637 Poznañ. Poland
}

\section{ABSTRACT}

The experiment was designed in a bifactor model with five maize hybrids (Rasant, Dragon, LG 2252, San and Magister), mowed at two heights, i.e., $10-12 \mathrm{~cm}$ (A) and $50 \mathrm{~cm}$ (B). The average yield of ory matter of plants cut at a height of $50 \mathrm{~cm}$ (B) was $130.5 \mathrm{dt} / \mathrm{ha}$ and was significantly lower than the yicld obtained from maize mowed at a height of $10-12 \mathrm{~cm}(\mathrm{~A})$, where it amounted to $148.1 \mathrm{dt} / \mathrm{ha}$. The percentage of ears showed the opposite trend, with 55.3 and $49.2 \%$, respectively. Dry matter in all silages ranged from 35.9 to $42.1 \%$. B silages contained more dry matter and starch, but less structural carbohydrate. Dry matter degradation in the rumen of these silages was increased (65.5$70.0 \%$ ). Effective ruminal degradability of crude protein of all of the investigated silages (80.0$86.5 \%)$ was in the same range as that of starch $(79.2-87.3 \%)$. A tendency towards reduced protein and starch degradabilities was observed in B silages. The average NDF loss after $24 \mathrm{~h}$ of ruminal incubation of silage samples produced from plants mowed at the traditional height (A) was 65.3 . $66.7 \%$.

KEY WORDS: maize, cultivar, chemical composition, effective degradability

\section{INTRODUCTION}

Maize silage is a valuable energetic component of feed rations for cattle (O’Omara et al., 1998; Mills et al., 1999; Ballard et al., 2001). Requirements concerning the nutritive value rise along with increasing milk yields of cows. The energy concentration in maize depends, among others, on the genotype (Philippeau and Michalet-Doreau, 1998) and mowing height at harvest (Michalski, 1987). 
Varieties giving kernels with lower ruminal starch degradability and good digestibility of structural carbohydrates gain importance in this respect (Löhnert et al., 1999). Mowing maize at a higher height than the traditional $10-12 \mathrm{~cm}$ results in an increased proportion of kernels to straw and a rise in the energy concentration in the obtained feed (Michalski, 1997).

The aim of this study was to determine the chemical composition and ruminal degradability of maize silages depending on the cultivar and mowing height at harvest.

\section{MATERIAL AND METHODS}

Cultivars selected for the experiment were those leading in the production of silage in 1998 in terms of dry matter yields in the case of whole plants. The investigations were conducted in the following year and included five hybrids grown on experimental plots, i.e., Rasant FAO 200, Dragon FAO 210, LG 2252 FAO 230, San FAO 240 and Magister FAO 270. Maize was harvested (harvester-Claas Jaguar) in the late dough stage and mowed at height $\mathrm{A}(10-12 \mathrm{~cm})$ and height $\mathrm{B}$ $(50 \mathrm{~cm})$. After being cut in a cylindrical chopper into chaff of approximately $7-\mathrm{mm}$ length, the maize was ensiled in small silos $\left(7 \mathrm{dm}^{3}\right)$, each variant in three replicates. Eight weeks later the silage was subjected to both chemical and in sacco analyses (Ørskov and Mc Donald, 1979) using cannulated Jersey heifers. Heifers were fed rations consisting of meadow hay ad libitum and $2 \mathrm{~kg}$ concentrate twice a day. Samples were incubated in the rumen for $0,2,4,8,12,24$ and $48 \mathrm{~h}$. Degradation constants $a, b, c$ were calculated with Stat Graph 5.0 software at the rate of ruminal outflow $\mathrm{k}=0.06$.

The nutrient content in feeds was determined using AOAC (1990) methods. Protein content was determined using Kjelfoss equipment, structural carbohydrates, using a Tecator device, whereas starch, according to Kozlowski (1994) with modified glucose determination on HPLC. The latter was also used to determine acids in silages.

The data were subjected to statistical analysis of variance using SAS software (1996). Duncan's multiple range test was used to test the significance of the difference between means.

\section{RESULTS}

Dry matter yield in the five investigated maize cultivars was on average $148.1 \mathrm{dt} /$ ha for the traditional (A) and $130.5 \mathrm{dt} /$ ha for the increased (B) mowing height at harvest. The difference between mowing heights for all the cultivars was con- 
firmed statistically, with $\mathrm{P}<0.05$. Significantly higher yields were obtained from the later varieties, San and Magister, when compared with the earlier cultivars, Rasant, Dragon, and LG 2252.

The percentage of ears in dry matter was 49.2 (A) and $55.3 \%$ (B), respectively. In this respect significant differences were observed only for mowing heights. Dry matter content in silages depending on the variety fell within the range of 35.9$38.2 \%$ (A) and $38.1-42.1 \%$ (B), respectively. Crude protein concentration in dry matter was $6.3-7.4 \%$ and $6.7-7.5 \%$, respectively. The content of structural carbohydrates was lower in silages made from maize cut higher in comparison with that mowed in the traditional way. The difference between A and B depending on the cultivar was $1.0-5.3 \%$ for crude fibre, $1.8-4.0 \%$ for ADF and $-0.1-4.0 \%$ for NDF, on a dry matter basis (Table 1$)$.

TABLE 1

Chemical composition of maize silages

\begin{tabular}{|c|c|c|c|c|c|c|c|c|c|c|c|}
\hline \multirow{3}{*}{ Item } & \multicolumn{10}{|c|}{ Variety } & \multirow{3}{*}{$\begin{array}{r}\begin{array}{r}\text { Significance } \\
\text { of effects }\end{array} \\
\mathrm{A} \times \mathrm{B}\end{array}$} \\
\hline & \multicolumn{2}{|c|}{ Rasant } & \multicolumn{2}{|c|}{ Dragon } & \multicolumn{2}{|c|}{ LG 2252} & \multicolumn{2}{|c|}{ San } & \multicolumn{2}{|c|}{ Magister } & \\
\hline & A & B & A & B & $\mathrm{A}$ & B & $\mathrm{A}$ & B & A & B & \\
\hline Dry matter, \% & 36.4 & 41.9 & 38.2 & 42.1 & 38.1 & 39.1 & 36.4 & 38.1 & 35.9 & 40.3 & $* *$ \\
\hline \multicolumn{12}{|l|}{ In dry matter, $\%$} \\
\hline crude protein & 6.3 & 6.7 & 7.1 & 7.5 & 6.5 & 7.1 & 7.4 & 7.1 & 6.6 & 7.0 & NS \\
\hline crude fibre & 24.4 & 19.1 & 21.3 & 19.7 & 24.0 & 19.3 & 23.0 & 22.0 & 22.6 & 18.4 & $* *$ \\
\hline $\mathrm{ADF}$ & 24.9 & 22.1 & 24.3 & 21.8 & 24.3 & 21.8 & 24.7 & 22.9 & 25.9 & 21.9 & $* *$ \\
\hline NDF & 47.8 & 47.9 & 47.6 & 45.5 & 48.6 & 45.5 & 51.0 & 47.0 & 47.8 & 45.1 & * \\
\hline starch & 23.1 & 25.6 & 24.3 & 25.4 & 22.1 & 23.0 & 24.8 & 24.8 & 23.8 & 24.4 & NS \\
\hline $\mathrm{pH}$ & 4.2 & 3.8 & 3.9 & 3.8 & 4.0 & 3.8 & 4.1 & 4.0 & 3.8 & 3.9 & NS \\
\hline \multicolumn{12}{|c|}{ In dry matter, $\mathrm{g} / \mathrm{kg}$} \\
\hline lactic acid & 36.0 & 30.3 & 43.7 & 36.1 & 35.8 & 37.8 & 45.6 & 40.6 & 37.6 & 33.5 & NS \\
\hline acetic acid & 7.4 & 6.2 & 11.2 & 10.4 & 8.4 & 8.1 & 4.7 & 8.5 & 7.2 & 7.4 & NS \\
\hline butyric acid & 0.8 & 0.5 & 0.5 & 0.9 & 0.5 & 0.5 & 0.5 & 0.5 & 0.8 & 0.5 & NS \\
\hline
\end{tabular}

${ }^{*} \mathrm{P}<0.05,{ }^{* *} \mathrm{P}<0.01, \mathrm{NS}-$ not significant

The starch content in the dry matter of silages produced from maize cut at height $\mathrm{A}$ fell within the range of $22.1-24.8 \%$, whereas for height $\mathrm{B}$ it was 23.0 $25.6 \%$. The smallest amount of starch was found in the silage made from the LG 2252 variety.

Effective ruminal degradability of dry matter in case of maize silages was lower for mowing height $\mathrm{A}(63.0-67.5 \%)$ and higher for B (65.5-70.0\%). Effective 
protein degradability was $80.6-86.5 \%$ and $81.1-82 \%$, respectively (Table 2 ). Effective starch degradability in the rumen fell within the range of $83.2-87.3 \%$ (A) and $79.2-86.8 \%$ (B). After $24 \mathrm{~h}$ ruminal incubation of samples A, NDF loss was determined. The highest NDF disappearance was observed for the Magister variety $(67.6 \%)$, whereas the lowest, for Rasant $(65.3 \%)$.

TABLE 2

Effective ruminal degradability, \%

\begin{tabular}{|c|c|c|c|c|c|c|c|c|c|c|c|}
\hline \multirow{3}{*}{ Item } & \multicolumn{10}{|c|}{ Varicty } & \multirow{3}{*}{$\begin{array}{r}\begin{array}{r}\text { Signiticance } \\
\text { of effects }\end{array} \\
\mathrm{A} \times \mathrm{B}\end{array}$} \\
\hline & \multicolumn{2}{|c|}{ Rasant } & \multicolumn{2}{|c|}{ Dragon } & \multicolumn{2}{|c|}{ LG 2252} & \multicolumn{2}{|c|}{ San } & \multicolumn{2}{|c|}{ Magister } & \\
\hline & A & B & A & B & A & B & A & B & A & B & \\
\hline Dry matter & 63.0 & 69.6 & 66.6 & 70.0 & 67.5 & 67.8 & 63.9 & 65.5 & 63.5 & 67.3 & $*$ \\
\hline Crude protein & 86.5 & 80.8 & 84.1 & 81.6 & 80.6 & 81.9 & 82.9 & 82.0 & 84.2 & 80.1 & * \\
\hline Starch & 87.0 & 81.3 & 87.3 & 84.1 & 84.3 & 86.8 & 83.2 & 82.8 & 83.8 & 79.2 & NS \\
\hline $\mathrm{NDF}^{\prime}$ & 65.3 & - & 67.2 & - & 67.2 & - & 67.0 & - & 67.6 & - & - \\
\hline
\end{tabular}

$* \mathrm{P}<0.05, * * \mathrm{P}<0.01$, NS - not significance

'disappearance after $24 \mathrm{~h}$ incubation of samples in the rumen

\section{DISCUSSION}

Maize, due to its yield and nutritive value, constitutes the basic energetic feed for ruminants, being fed primarily in the form of silage (Michalski, 1987). New cultivars are being introduced and harvesting methods are being improved to meet the requirements of high-yielding animals (Philippeau et al., 1999; Kruczyńska et al., 2000). Mowing maize at various cutting heights resulted in significant changes in the yields of dry matter and the quality of raw material for ensiling. As a consequence of increasing mowing height from $10-12 \mathrm{~cm}$ to $50 \mathrm{~cm}$ above the ground, the percentage of ears rose to approx. $55 \%$ of dry matter, while the total yield of plant dry matter decreased by $12 \%$. Later cultivars, San and Magister, gave the highest yields.

Dry matter in all maize silages considerably exceeded the optimum, i.e., 28$33 \%$ (Michalski, 1997). A very warm summer and little precipitation in the second half of the year characterized the year 1999. In the studies reported by Johnson et al. (1999) raw material quality deteriorated as the maturity of maize to be ensiled increased from 36 to $46 \%$. Experimental silages showed advantageous chemical composition.

Harvesting maize at the higher mowing height $(50 \mathrm{~cm})$ resulted in a lowered content of crude fibre and ADF, and increased starch content in the silage dry 
matter. However, the starch concentration was lower and that of NDF, higher than could have been expected on the basis of the approx. 55\% proportion of ears in the dry matter of plant yield. Harvesting maize at the dough stage makes it possible to obtain approx. 30\% of starch in dry matter (Flachowsky, 1999; Löhnert et al., 1999). According to Thaysen (1999), changing the mowing height of maize from $15-20 \mathrm{~cm}$ to $40 \mathrm{~cm}$ results in advantageous changes in chemical composition and in 5-10 higher energy concentration in the silage. Energy concentration in the silage is a consequence of its composition and digestibility. Effective degradability of silage dry matter ranged from 63.1 to $70.0 \%$, favouring the increased mowing height.

The issue here is to what degree and where both protein and starch are digested in the digestive tract of ruminants (INRA, 1993). Effective protein ruminal degradability in the case of maize silages, amounting to $80.0-86.5 \%$, is considered to be high when compared with INRA data (1993). Starch in maize silages well lacerated prior to ensiling and again before they were inserted in the rumen was degraded in $79.0-87.3 \%$. Flachowsky (1999) reported that the average for different cultivars was $80 \%$. Philippeau et al. (1998) demonstrated that both ensiling and milling significantly increase ruminal starch degradation. In their studies the degradation of milled and ensiled Dent maize kernels amounted to $91.1 \%$, whereas for the Flint type it was $82.0 \%$. However, starch of mature dry maize kernels shows lower ruminal degradability (Philippeau et al., 1999).

As a consequence of increased mowing height, a tendency towards a reduction in crude protein and starch degradabilities was found in the investigated silages. The degradation of NDF after $24 \mathrm{~h}$ ruminal incubation of the samples ranged from 65.3 to $67.6 \%$. Südekum (1999) reported after de Visser that effective NDF ruminal degradability was $66 \%$, being lower than the NDF degradability in case of grass silages, which contain a bigger amount of this carbohydrate fraction.

\section{CONCLUSIONS}

Changing the mowing height at harvest from $10-12 \mathrm{~cm}$ to $50 \mathrm{~cm}$ results in a significant increase in the percentage of ears in dry matter and a simultaneous decrease in the total yield. This is reflected in the chemical composition of silage, i.e., lower crude fibre and ADF contents and greater starch content. At the same time, dry matter ruminal degradation increases with a simultaneous tendency towards reduced starch and protein degradations.

The conducted investigations confirm the high and similar quality of selected maize hybrids, as well as the nutritive value of silages made from them. 


\section{REFERENCES}

AOAC, 1990. Association of Official Analytical Chemists, Official Methods of Analysis. $15^{\text {th }}$ Edition. Arlington, VA

Ballard C.S., Thomas E.D., Tsang D.S., Mandebvu P., Sniffen C.J., Endres M.I., Carter M.P., 2001. Effect of corn silage hybrid on dry matter yield, nutrient composition, in vitro digestion, intake by dairy heifers, and milk production by dairy cows. J. Dairy Sci. $84,442.452$

Flachowsky G., 1999. Glucose - ein Schlüssel für hohe Leistungen. Arbeiten der DLG/Band 196. Fütterung der 10.000-Liter-Kuh. DLG Verlag, pp. 43-56

IZ, 1993. Research Institute of Animal Production. Standards for Cattle, Sheep and Goat Nutrition (in Polish). Omnitech Press, Warszawa (Poland)

Johnson L., Harrison J.H., Hunt C., Shinners K., Doggett C.G., Sapienza D., 1999. Nutritive value of corn silage as affected by maturity and mechanical processing: a contemporary review. J. Dairy Sci. $82,2813-2825$

Kozlowski F., 1994. L'amidon, quel dosage pour quel echantillon? Cah.Techn. INRA 35, 5-22

Kruczyńska H., Darul K., Michalski T., Nowak W., 2000. Chemical composition and ruminal degradability of dry matter and crude protein from maize silages and dry matter from maize grain. Ann. Anim. Sci.-Rocz. Nauk. Zoot. 27 (4), 271-278

Löhnert H.J., Ochrimenko W.1., Schwartze J., 1999. Inhaltsstoffe und Verdaulichkeit der Rohnährstoffe verschiedener Silomaissorten. Rekasan J. (11/12), 56-57

Michalski T., 1987. The influence of height cut at harvest on yield and nutritive value of maize silage (in Polish). Rocz. AR Poznań, CLXXXVI, 6l-73

Michalski T., 1997. The nutritive value of maize depending on methods and date of harvest (in Polish). Zesz. probl. Post. Nauk rol. No. 450, 133-162

Mills J.A., France J., Dijkstra J., 1999. A review of starch digestion in the lactating dairy cow and proposals for a mechanistic model: 1.Dietary starch characterisation and ruminal starch digestion. J. Anim. Feed Sci. 8, 291-340

O'Omara F.P., Fitzgerald J.J., Murphly J.J., Rath M.,1998. The effect on milk production of replacing grass silage with maize silge in the diet of dairy cows. Livest. Prod. Sci. 55, 79-87

Ørskov E.R., Mc Donald J., 1979. The estimation of protein degradability in the rumen from incubation measurements weighted according to rate of passage. J. Agr. Sci. 88, 499-503

Philippeau C., Michalet-Doreau B., 1998. Influence of genotype and ensiling of corn grain on in situ degradation of starch in the rumen. J. Dairy Sci. 81, 2178-2184

Philippeau C., Le Deschault de Mondredon F., Michalet-Doreau B., 1999. Relationship between ruminal starch degradation and the physical charactristics of corn grain. J. Anim. Sci. 77, 238243

SAS ${ }^{3 *}, 1996$. User's Guide: Statistics, Version 6.12. SAS inst., Inc., Cary, NC

Südekum K-11,,1999. Zellwände bringen Struktur ins Futter. Arbeiten der DLG/Bd 196. Fütterung der 10.000-Liter-Kuh. DLG Verlag, pp. 57-64

Thaysen J., 1999. Spitzensilagen und wic Man sic Macht. Arbeiten der DLG/Bd 196. Fütterung der 10.000-Liter-Kuh. DLG Verlag, pp. 103-126 


\section{STRESZCZENIE}

Sklad chemiczny i rozkład w żwaczu suchẹj masy, bialka i skrobi kiszonek z kukurydzy w zależności od odmiany i wysokości cięcia przy zbiorze

Do badań użyto pięć mieszańców kukurydzy: Rasant, Dragon, LG 2252, San i Magister, ścinanych na dwóch wysokościach:10-12 cm (A) i $50 \mathrm{~cm}$ (B). Średni plon suchej masy roślin ściętych na wysokości $50 \mathrm{~cm}$ (B) wynosił 130,5 dt/ha i był istotnie mniejszy od plonu (A) 148,1 dt/ha. Udział kolb wynosił odpowiednio 55,3 i 49,2 \%. Zawartość suchej masy we wszystkich kiszonkach wynosiła od 35,9 do $42,1 \%$. Kiszonki B zawierały więcej suchej masy i skrobi, a mniej strukturalnych węglowodanów. Efektywny rozkład w żwaczu białka ogólnego wszystkich badanych kiszonek (80,0$86,5 \%)$ był podobny jak skrobi $(79,2-87,3 \%)$. Zaznaczyła się tendencja mniejszego rozkładu białka i skrobi w żwaczu w kiszonkach B. Średni ubytek NDF po 24 godzinach inkubacji w żwaczu prób kiszonek z roślin ścinanych tradycyjnie (A) wynosił 65,3-67,7\%. Zwiększenie wysokości cięcia roślin przy zbiorze przyczyniło się do istotnej poprawy wartości pokarmowej kiszonek. 